\title{
War of conscience: anti-vaccination and the battle for medical freedom during World War One
}

Prof Susan McPherson, School of Health and Social Care, University of Essex, Wivenhoe Park, Colchester CO4 3SQ, UK Email: smcpher@essex.ac.uk

\begin{abstract}
The nineteenth century British anti-vaccination movement attracted popular and parliamentary support and ultimately saw the 1853 law which had made smallpox vaccination compulsory nullified by the 1898 'conscientious objector' clause. In keeping with popular public health discourse of the time, the movement had employed rhetoric associated with sanitary science and liberalism. In the early twentieth century new discoveries in bacteriology were fuelling advances in vaccination and the medical establishment was increasingly pushing for public health to move towards more interventionist medical approaches. With the onset of war in 1914, the medical establishment hoped to persuade the government to introduce compulsory typhoid inoculation for soldiers. This article analyses anti-vaccination literature, mainstream newspapers and medical press along with parliamentary debates to examine how the British anti-vaccination movement engaged with this new threat of compulsion by expanding the rhetoric of 'conscience' and emphasising medical freedom while also asserting scientific critique concerning the effectiveness of vaccines and the new laboratory based diagnostic practices. In spite of 'conscience' fitting well with an emerging public health discourse of individual subjectivity, the mainstream press ridiculed the idea of working class soldiers having a conscience, coalescing around the idea that 'conscientious objection' be reserved for spiritual, philosophical and educated men who objected to military service. Moreover, in spite of engaging in reasoned scientific critique, parliament and press
\end{abstract}


consorted in the demarcation of scientific knowledge as exclusive to medical scientists, reflecting a growing allegiance between the state and the medical establishment during the war. Any scientific arguments critical of medical orthodoxy were subjugated, labelled as 'crank' or 'faddist' as well as unpatriotic. The anti-vaccination narratives around conscience contributed to or were part of an evolving discourse on consent and ethics in medicine. Potential parallels are drawn with current and likely future debates around vaccination and counterhegemonic scientific approaches.

\section{Introduction}

In the second half of the nineteenth century, the British anti-vaccination movement highlighted a paradox in the cotemporary sanitary science movement in its promotion of the 1853 Vaccination Act which enforced compulsory vaccination against smallpox. This was seen as antithetical because as far as the anti-vaccination movement was concerned, vaccination was an insanitary procedure in which unclean animal matter was effected to pass into the blood, leaving a gaping wound on the skin which often became infected. ${ }^{1}$ The antivaccination movement was firmly pro-sanitation as the sole effective public health measure and worked tirelessly to highlight the error in allowing vaccination to form part of a sanitary public health policy. ${ }^{2}$

The movement attracted popular and parliamentary support in Britain during the latter part of the nineteenth century and ultimately saw a change to the law in the form of the conscientious objector clause in $1898 .^{3}$ Along with flourishing movements in vegetarianism, teetotalism, anti-tobacconism, naturopathy and herbalism, the movement had contributed to the 
circulation of popular discourse about the danger of dirt and the sanctity of the body boundary, essential for the promotion of 'sanitary science', referring to scientific truth claims underpinning sanitation as the cornerstone of public health policy. ${ }^{4}$ Anti-vaccination leaflets, journals and campaign materials drew directly on the rhetoric of sanitary science, appealing to the public fear of filth entering the body which they combined to good effect with a rhetoric of liberalism. ${ }^{5}$

The apparent success of the anti-vaccination movement coincided with the flourishing of Liberalism in politics and philosophy from 1859 when Mill published 'On Liberty' and a Liberal Party was formed in Britain. Anti-vaccinationists achieved very effective propaganda by linking the discourse of dirt with Mill's concept of all-encompassing personal liberty, including "liberty of thought and feeling; absolute freedom of opinion and sentiment on all subjects, practical or speculative, scientific, moral or theological”. Liberal ideals were a critical plank of anti-vaccinationist material. Mill specifically said of health that "each is the proper guardian of his own health, whether bodily, or mental and spiritual. Mankind are greater gainers by suffering each other to live as seems good to themselves, than by compelling each to live as seems good to the rest."6

Sanitation was primarily advocated by public health officials, controlled by government and bureaucrats influenced to varying degrees by Liberal ideology. The medical profession, meanwhile, was more interested in medical science, curative interventions, surgical advances and the forward march of microbiology. ${ }^{7}$ Anti-vaccinationism then, was labelled by the medical establishment as anti-medical. The knowledges they represented were subjugated by establishment medicine which sought to push the doctrines of natural remedies and 
prevention out of the health market. ${ }^{8}$ Societies and movements critical of these approaches were decried as 'cranks' or 'faddists', a mark of a subjugated knowledge: "a manoeuvre that defines certain practices and beliefs as trivial, and a certain political praxis as peripheral rather than central." ${ }^{\prime 9}$ The move to fortify the medical profession and outlaw 'cranks' came at a time when the boundaries of medical orthodoxy were still being negotiated. ${ }^{10}$ The professionalization of medicine was in its early days with the establishment of the General Medical Council in 1858 and the 1886 Medical Acts Amendment Bill outlawing 'untrained' practitioners. The anti-vaccination movement, having gained public appeal and political currency at the peak of Liberalism, would find the rise of establishment medicine during the next century a more difficult terrain.

Armstrong has described how around the turn of the twentieth century, the predominance of sanitary science as a regime gave way to 'personal hygiene'. ${ }^{11}$ In this new doctrine, danger was no longer in nature and dirt, but in other bodies. This is reflected in the growing popularity of germ theories in medical science which emerged around the end of the nineteenth century, giving rise to the science of bacteriology and the hunt for microbes. ${ }^{12}$ Germ theory evolved as studies by Pasteur, Koch and Lister in the late nineteenth century became widely publicised, providing more convincing theoretical basis for Jenner's smallpox discoveries. ${ }^{13}$ Thus, medical scientists promoting bacteriology began to gain influence among policymakers. This opened up a potential, through promotion of population based medical prophylaxis, for public health to align with medical science and move away from the primacy of hygiene. 
Armstrong notes a shift in public health narratives at this time away from concerns with dirt and sanitation and towards concepts of individual identity, individual subjectivity and psychosocial spaces; hence the emergence also of new disciplines in psychology, psychoanalysis, sociology and social medicine. ${ }^{14}$ This is evident in what Durbach describes as a national debate stimulated by the 1898 Conscientious Objector clause concerning the nature of the modern subject: "who exactly was entitled to make a claim to possess a conscience, with its concomitant rights, was itself a contested issue." ${ }^{15}$ Durbach notes that the anti-vaccination campaign of the nineteenth century had successfully mobilised the working class. The idea that all persons might possess a 'conscience' (rather than only deep thinking spiritual men) was now a discursive possibility. Yet the vast majority of certificates for conscientious objection to smallpox vaccination were issued to working class mothers on behalf of their infants. Hence, Durbach explores how conscience became class and gender based and, comments that "many working class soldiers deeply resented the conscientious objector to military service who was often depicted as the effete upper-class sissy epitomized by the intellectuals and pacifists of the Bloomsbury Group". ${ }^{16}$ This depiction clearly also highlights problematic notions of ideal masculinity at the time. The current paper will look beyond class and gender and consider the ways in which the debate also reflected growing tensions between the increasingly influential medical establishment and those deemed to be 'anti-medical', how this influenced government policy and fed into developments in medical ethics.

While other anti-vaccination societies closed down after the conscientious objection was introduced, the National Anti-Vaccination League (NAVL) continued. The principles and practices of vaccination beyond smallpox were gaining increasing currency, especially in the 
context of the Armed Forces whose leaders were acutely aware from experiences in the Boer War of the devastation caused by infectious diseases including smallpox, cholera, dysentery and typhoid. ${ }^{17}$ At the time of the Boer War (1899-1902), a new inoculation for typhoid had been tested almost simultaneously in Britain by Sir Almroth Wright and in Germany by Koch, bringing to the fore debates around the merits of military hygiene versus medical prophylaxis.

Hardy has detailed the alternating course of this debate in Britain from the Boer War to World War One, highlighting the dynamic and contrasting priorities of the government, the Armed Forces and the bacteriologists keen to see military compulsion introduced. ${ }^{18}$ Linton has similarly traced the developments of scientific and political debates in Germany over this period leading to military compulsion in Germany. ${ }^{19}$ Both these accounts focus primarily on the arguments and evidence put forward by bacteriologists and the difficulties they had persuading governments of the efficacy and safety of typhoid inoculation. In particular, Hardy details the arguments British bacteriologists made to counter the anti-vaccinationist threat, concluding that anti-vaccinationists were, in the end, "successfully routed" in terms of high levels of voluntary uptake. This infers that the goal of anti-vaccinationists was to disrupt the use of an evidently effective medical tool rather than to preserve the principle of liberty and resist the dominance of a single scientific doctrine.

Walker examines typhoid inoculation using oral histories of soldiers and concludes that the strategies of persuasion adopted by the British Army were compulsion in all but name and that the debates it conjured reflected a tension between individual freedoms and the "greater good". Focusing on the loss of bodily autonomy (rather than subjectivity) through military 
training, diet, uniforms, medicines and vaccinations, Walker concludes that resistance to loss of bodily autonomy of soldiers at time of war was futile. ${ }^{20}$ None of these three accounts examine in detail the rhetoric employed by British anti-vaccinationists and how they responded to attacks by the medical establishment and media. Specifically, while these previous accounts allude in different ways to the motives, success or failure of the antivaccination movement to disrupt compulsory typhoid vaccination, none consider in detail the ways in which their rhetoric conjured and shaped the compulsion debate; the types of knowledge claims made; nor tensions it revealed between Liberal ideology and advances of medical science and implications for the development of twentieth century medical ethics.

The present paper provides a discursive examination of the rhetoric employed by (and against) the British anti-vaccination movement between 1914 and 1919. Based on NAVL literature, the British Medical Journal, British newspaper articles and Hansard records of the period concerning vaccination, the paper examines the ways in which the NAVL engaged rhetorically with scientific arguments, parliamentary debates, mainstream media and pacifist arguments to strengthen objections to compulsory vaccination. NAVL literature cited throughout is from the Vaccination Inquirer and Health Review which was a monthly publication referred to on every front page as the 'Organ of the National Anti-Vaccination League'. It had been in print since 1879 and had formed a key component of a highly effective anti-vaccination propaganda campaign during the late nineteenth century. ${ }^{21}$ Each monthly issue consists of about 20 pages of material, mostly anonymous opinion articles with only one regular feature referring to a specific author ('Mr Thirtle's notes'). The present paper uses quoted material from this publication throughout, taken to represent the views of 
the NAVL as an organisation rather than any particular individual, given the anonymised nature of the material.

\section{Liberty versus Prussianism}

At its outset in 1914, the 'European War' was sold to the British people as a liberal crusade. Although the "fundamental instincts" of nineteenth century Liberalism were "a belief that peace is the common interest of all mankind"

...running through Liberal policy there have been two distinct (and apparently inconsistent) tendencies. The first has sought to restrict the interference of this country in foreign affairs to a minimum... The second has passionately endorsed the claims of "peoples struggling to be free" and has been eager to go crusading on behalf of popular liberties throughout the world. $^{22}$

It was the latter that held sway in popular rhetoric at the outbreak of war and the NAVL adopted this rhetoric to embrace the war and assert its patriotism:

In our smaller and less spectacular way we are waging war at home the same fight as our armies abroad. They fight for the liberties of Europe, for the protection and maintenance of small communities against the blind aggression of unscrupulous numbers. That is our task too. $^{23}$

'Prussianism' was the metaphor of the moment for all forms of authoritarianism. Germany had been rigorous with compulsory vaccination and led developments in vivisection, enabling 
the NAVL as a "small community" to immediately declare a moral victory at the start of the war:

The downfall of Prussianism: the material overthrow of Germany is yet distant, but her moral and intellectual prestige is in moral collapse... The evils waiting on the regimentation of a whole nation and the heavy imposition of authority; the stifling of the spirit, the crippling of mental freedom and elasticity, the dulling of personal conscience and sensibilities, the fostering of laborious pedantry: these things lay below the surface and hidden from the careless observer. German thoroughness in vaccination, the wonderful discoveries with which her vivisectional laboratories teemed, were quoted against us again and again. ${ }^{24}$

Effectively denouncing bacteriology and its supporters as authoritarian German sympathisers, the NAVL nevertheless found themselves on an oppositional footing to the British government and saw themselves denounced as unpatriotic. In 1908, the Liberal Secretary of State for War had stated that territorial (volunteer) soldiers would not be subject to compulsory (smallpox) vaccination as were the regular army. The NAVL believed they had been responsible for extracting this pledge, ensuring the swelling numbers joining Kitchener's Army. But as the NAVL began to report on instances of volunteers forced illegally into vaccination, ${ }^{25}$ the government's broken pledge became a common theme. "We are amazed to learn that the assurances under which the territorials were induced to enlist are but air, that their freedom from forcible violation of conscience is but a sham."26 This was the start of a battle to claim soldiers as bodies with more than mere bone, muscle, sinew and blood, but as subjective beings possessing a conscience. 
Britain had instituted widespread typhoid inoculation for soldiers in earlier campaigns in India and South Africa at the persuasion of Wright, the eminent British bacteriologist who had developed anti-typhoid inoculation. Yet, while Wright was highly respected by many in his field and esteemed by the British establishment, receiving a knighthood in 1906, Hardy notes that in the public eye, "he was also an erratic and disputatious public figure, known and disliked for (among other things) his attitude to women and his opposition to women's suffrage." ${ }^{27}$ Wright's poor public image, arrogance and failure to provide robust statistical support for its safety and efficacy along with heightened public awareness of issues of individual rights and conscience meant that his calls for compulsion were resisted and the programme suspended in $1904 .^{28}$ The outbreak of war in 1914 was an opportunity for Wright to reinvigorate his efforts to press for military compulsion.

Wright was aware of the potential for opposition to compulsion: "If opposition comes...it will come from that kind of person who by his personal aversion to the principle of compulsion in anything, has brought down upon us, as our Nemesis, this European War."29 The NAVL retorted, "Considering that Prussia, which engineered the war, is distinguished above everything,...by its whole hearted enthusiasm for the 'principle of compulsion in anything', it would be difficult to frame a more pointless fatuity." ${ }^{30}$ The NAVL continued to agitate against typhoid inoculation by distributing leaflets amongst troops at recruiting stations. Under the heading "Captured by the Prussians" 31 the NAVL, with ample melodrama, describe an incident in which two of its members were forcibly detained by army officers while handing out anti-inoculation leaflets. 
In spite of a strong mixture of rhetoric mingling liberalism and conscience, the NAVL came under heavy fire for their stance against inoculation. In the early months of the war, the most deadly weapon against any individual or organisation was the decry of 'unpatriotic', hence the initial emphasis in NAVL literature of their established opposition to 'Prussianism'. The NAVL recoiled at the accusation: "We had thought to have 'hitched our wagon to a star', and that the oriflamme of freedom, floating at the battlefront of the Allies was ours as well, by community of principle. Not so." 32

The pummelling of the NAVL became fierce. In December 1914, a debate on inoculation at the Royal Sanitary Institute reportedly ended in disorder as the chairman was accused of attempting to stifle discussion. Speaking at the event, William Leishmann (Medical Director of Army Medical Services) spoke about his abhorrence of the anti-inoculation movement, apparently declaring that he would "commit greater atrocities than those which had been witnessed even in Belgium, could he 'get at these people"'. Similarly, the Dean of St Pauls wrote to the NAVL, "Sir, I cannot imagine a more disgraceful or unpatriotic agitation than that in which you are engaged. If I were at the head of affairs, I should have you shot summarily." 33

These quotes helped the NAVL to associate inoculationists with Prussianism. But while these verbal assaults took place on the Home Front, the soldiers were amassed on battlefields abroad. A rhetorical battle ensued concerning whether these bodies were merely anatomical clusters moving about in the dirt ridden battlefields or conscientious beings. The NAVL attempted to defend soldiers' rights to a conscience, unified as 'the objecting class', united by belief in individual liberty, many of whom wrote to the NAVL about their experiences: "The 
letters we have published are representative of the objecting class and our readers can judge for themselves whether the writers give the impression of being perverse blockheads as our army medicos would have us believe." 34

In parliament, the NAVL had a spokesperson, Henry Chancellor, a Liberal MP who had also been an active campaigner for teetotalism. He fought vehemently for the soldier's conscience in parliament:

We are supposed to have entered upon this War with an ideal object, and we are fighting against a certain set of ideas. One of those ideas is that 'might is right', and we hope to dethrone and disestablish that idea as the result of our efforts... They are men who believe that this particular form of medical treatment is wrong, and they refuse to violate their consciences by complying with the demands of their officers. ${ }^{35}$

But other parliamentarians, such as Scottish Unionist MP Sir Henry Craik and the medical doctor turned Liberal MP Christopher Addison, denied soldiers their conscience and indeed their ability to think for themselves:

Craik: It is not the poor soldiers who are to blame. It is the men who stir up this opposition, who would fain break the bounds of discipline and who teach these men that they are as fit judges of this difficult question as those who have spent their lives upon it and have commanded the respect of all the scientific world. 
Addison: I think a good many men might find their consciences more or less asleep on this subject had it not been that somebody or other made it their business to go about among all the camps distributing leaflets. ${ }^{36}$

It appears the NAVL had at the start of war assumed that since the war was pitched as a Liberal crusade, they would easily drum up public and government support for their longstanding steadfast opposition to 'Prussianism', the Germans having long been seen as 'triumphalist' about their expansive contributions to bacteriology. ${ }^{37}$ The Prussian medical police was considered illustrative of a stark difference between German and British values and bureaucratic traditions, the latter favouring education and persuasion over compulsion in matters medical. ${ }^{38}$ Yet as the brutal reality of trench warfare preventing fulsome sanitary measures along with reports of German atrocities, it seems there was a powerful counternarrative advancing the idea that Liberal ideals must give way to stark necessity.

The NAVL found themselves accused of treachery, clinging to Liberal ideals in the face of national annihilation. Parliamentary narratives supporting inoculation asserted that the legions of patriots signing up accepted the need to abandon individual rights in favour of the "greater good". ${ }^{39}$ Indeed, it has been suggested that the German tendency towards compulsion in medicine and medical policing was no more that semantics; that the practice of British state medicine always had been a form of policing. ${ }^{40}$ The NAVL appear confounded by what was to them a renunciation of a core British value: medical freedom. Resisting defeat, they attempted to reach across class boundaries to rally 'the objecting class', presumably men and women of all classes willing to stand up for their rights, the primacy of individual freedom and the requisite principle of conscientious objection. 


\section{Statistics and Methods: Diversionary Tactics}

Following the 1915 House of Commons debate on compulsory typhoid inoculation, the War Office delayed a decision indefinitely. Meanwhile, battles over statistics and methodology ensued. Arguments over the value of inoculation were initially based on statistics from the Boer War and British forces in India. The NAVL argued that wherever figures for typhoid showed a reduction following inoculation, this could be accounted for by increased sanitation or by the sleight of hand played by bacteriology in which cases of typhoid were re-labelled as newly identifiable diseases such as 'paratyphoid'. Medical men and the government declared with equal confidence that the figures available proved the miraculous benefits of inoculation. Where figures were in doubt, parliamentarians such as Arthur Lynch (an Irish MP with military experience in South Africa) were ready to accept opinion from eminent scientists:

Far better, I think, than statistics would be the weight of opinion of men whose whole scientific lives have been immersed in these questions,... [a] great living bacteriologist, Sir Almroth Wright, who is perhaps one of the most illustrious of all, and whose name is known all over the world as that of an extremely conscientious man in his work... has never yet given an opinion which is not based on scientific tests in what are known as 'controlled' cases... ${ }^{41}$

While politicians may have helped to entrench the common assumption that illustriousness equates to unquestionable wisdom, the NAVL were armed with scientific critique and argued that Wright cared little for 'controlled' research: "Of course all depends on whether the two 
classes, similar otherwise, are equally exposed to equally insanitary conditions, and Sir Almroth does not waste time over such difficulties." $" 42$

As the war progressed, statistics became available directly relating to the European Front which appeared to reveal remarkably few cases of typhoid. The government claimed this as a victory for inoculation while the NAVL noted that since inoculation had not been instituted at the very start of the war, the Expeditionary Force was mostly un-inoculated whilst "the hygienic requirements of the army have... been well provided for," 43 hence the initially low typhoid figures were taken as a victory for sanitation.

Blood samples from suspected cases of typhoid were being sent back to bacteriology laboratories at Home and these appeared to show that typhoid figures had fallen even lower as many suspected cases were found to be paratyphoid, dysentery or trench fever. The NAVL contested these data and claimed that clinically identical syndromes were but pseudonyms for typhoid invented by fraudulent bacteriologists, "Why should there be any differentiation in the nomenclature of diseases which 'it is quite impossible to diagnose clinically' one from the other?"44

However, with the focus having shifted to disembodied blood samples and data, the conjuring of soldiers' consciences was difficult to effect, while the state of their bodies in medical camps in France remained invisible to the public eye. Doctors in the field were only capable of clinical diagnosis, a technique eclipsed by the new laboratory technologies which claimed to be superior. The possibility for the great mass of soldiers in the field to demonstrate the 
workings of a conscience to an audience at home was being eroded by talk of numbers and scientific methods.

The NAVL attempted to keep the subjectivity of individual soldiers in the discursive realm through their abundant use of anecdotes. The NAVL published letter after letter from soldiers who had been perfectly healthy prior to signing up, complaining of being forced to submit to vaccination or inoculation, of experiencing negative side effects or worse; and from family members of soldiers who had died following inoculation including cases in which coroners refused to acknowledge the 'true' cause of death. Chancellor and other sympathetic MPs regularly introduced a selection of cases in parliamentary questions to Under Secretaries of State for War (first Tennant and latterly MacPherson), ensuring that certain cases gained notoriety and put the government under pressure to investigate. The NAVL regularly stressed the good British character and conscientiousness of the soldiers who resisted: "We rejoice that the country can still furnish in such numbers young men of moral courage and independent mind, who will not allow the army to be turned into a herd of conscienceless Prussians. $" 45$

Sir William Osler, Professor of Medicine, attempted to counter the abundance of anecdotes by inviting doctors countrywide to refer him all cases of untoward effects of inoculation so that he could properly investigate. ${ }^{46}$ But the impact of the personal stories of widows, bereaved mothers, astonished landladies and aggrieved, disabled men who had only wanted to serve their country was difficult to counteract, particularly given the sheer volume of cases reported. 
There was another interpretation of the increasing numbers of men, initially deemed healthy by recruiting officers, suddenly being taken ill or dying after inoculation. Before long, questions began to emerge of the poor health of recruits owing both to the negligence of recruiting officers and the supposed degenerating health of the nation. The notion of physical degeneration in Britain initially emerged in response to reports of high volumes of Boer War recruits being turned away. Contemporary analysis of this suggests this was but a myth projected by various actors favouring policies promoting temperance, better nutrition and more exercise among the working classes; indeed a gendered myth since it was working class women ultimately targeted for interventions such as education on budgeting, cooking, better parenting and moral behaviour. ${ }^{47}$

The myth of degeneration revived during World War One served a useful counter to the flood of anecdotes which had potential to sabotage public faith in typhoid inoculation. Measures to counter recruitment of bodies with hidden diseases included the 1916 Public Health (Tuberculosis) Regulations which aimed to prevent recruitment of TB carriers. The depiction of British bodies harbouring hidden diseases at home or amassed on the battlefields, inflicted with new diseases such as 'trench foot' and 'trench fever', formed in dirty, insanitary waterlogged trenches was perhaps useful as an image which it would be difficult to couple with the idea of hosting a conscience. Conditions of war for soldiers harked back to the days of early nineteenth century poor sanitation such that the discourse of subjectivity and conscience now seemed inappropriate.

Thus, having perhaps noticed that ideological arguments had lost their potency, the NAVL campaign engaged directly with scientific arguments on scientific terms. In challenging 
Bacteriology's scientific rigour, they asserted their own scientific expertise and mobilised scepticism among MPs as well as Wright's fellow medics, no doubt aware that throughout his career Wright had demonstrated numerous failings as a record keeper and researcher, despite his important discoveries. ${ }^{48}$ The NAVL challenge to the impossibility of rigorous controlled experiments in war conditions was understood as a valid critique and the simultaneous use of anecdote worked as a powerful counter narrative to the sterility of statistics in the public and political imagination.

\section{Press Blackout}

Although the NAVL was at liberty to choose its own discourse on conscientious objection in its own literature, it was unlikely to succeed in capturing public and political attitudes without support from mass media. The Times and The Daily Mail, both owned by the wealthy and influential Viscount Northcliffe, along with the Daily Express represented the most influential papers amongst the general public and intellectual elite. ${ }^{49}$ Daily readership of newspapers in Britain increased rapidly from 1896 to 1950, allowing newspaper owners strong influence on British attitudes. ${ }^{50}$

The Times published Wright's 1914 'manifesto' calling for compulsory inoculation of troops. ${ }^{51}$ The manifesto was followed by letters of support from leading medical men including William Leishmann, William Osler and Lauder Brunton. No letters appeared challenging the proposal and thereafter The Times appears to have avoided publishing any views sympathetic to anti-vaccination. George Bernard Shaw's letters (printed by the NAVL) were rejected: "it is really getting beyond a joke when The Times refuses a hearing to $\mathrm{Mr}$ Shaw." $" 52$ 
The Times adopted a wholesale pro-inoculation stance: "These two people, Sir Almroth Wright and Sir William Leishmann, have between them saved this people more precious lives than it is possible to reckon." ${ }^{, 53}$ But in spite of their support for inoculation, The Times ultimately warned against compulsion: "Afterall it appears that 90 percent of men voluntarily accept inoculation, and it might do more harm than good to create friction which can be avoided." 54 This suggested that the power of the libertarian principle was still understood to have public resonance, but the idea of soldiers' conscience was a stretch too far, particularly at a time of national crisis dependent on maximising the number of men available for the frontline. Thus, in spite of the NAVL's alliance with the paper's liberal principles, The Times reserved a hostility towards the organisation on a par with their enthusiasm for inoculation: "It is something worse than unpatriotic to endeavour, as is most regrettably being done, to persuade our soldiers to resist. ${ }^{55}$ The Daily Express was more derogatory, opining "the hour of cranks, faddists and gasbags has been sounded by the national call to arms." 56 The Daily Express published pieces directly addressed to soldiers, encouraging them to accept inoculation, downplaying side effects: "I don't want to die of typhoid, if a nice dose of germs, a few shivers, a sore arm, and a cosy morning in bed can prevent it!"57

The press hostility towards anti-vaccinationists extended to calls for the use of strong measures to prevent 'cranks' from operating, which was matched by questions in parliament about whether government would use the Defence of the Realm Act to suppress agitation against inoculation. ${ }^{58}$ The NAVL argued the War Office had gone too far in its suppression of media although their spokesperson acknowledged the inevitability of some suppression of liberty owing to the war: 
Chancellor: Is this War to be allowed to undermine all our liberties? I do not agree with many of the criticisms addressed to the Press Censor. I believe that his function is one that must be performed at a time like this, but is it to extend to questions of health $?^{59}$

In their own journal, the NAVL rhetoric against press censorship was stronger:

The Suppress Gang: the Inoculationists would appear to have succeeded in rushing the press, with the aid of what we understand is very vigorous pressure from the War Office. Fleet Street has never taken an independent view of medical controversies, and when the rain of titled medicine men who happened to be in the ascendant, tell them a thing is so, they generally lie down and cease to struggle. ${ }^{60}$

Here the NAVL allude to the increasing influence that the medical establishment had over the mainstream press and belittle the media for failing to resist this pressure, perhaps hoping this would rally their support base to resist the propaganda. However, the mainstream press had far greater circulation and therefore greater influence than 'crank' movement literature. The mainstream press rarely used the term 'conscientious objection' in reference to vaccination or inoculation. Instead, the terms 'cranks' and 'faddists' were common place for the agitators and soldiers were apparently under their influence: "In many cases, the poisonous influence of the cranks - whose only idol is their distorted temperament - was apparent, but I never found a 'conscientious objector' who could give even the haziest outline of his philosophy."61 The use of quotation marks around 'conscientious objector' implied this was an inappropriate term for someone not able to articulate a philosophy. Soldiers, therefore, were distinctly 
lacking in individual subjectivity since they were easily controlled either by military officers or by anti-vaccinationist agitators and had no mind of their own.

\section{Military Dictatorship}

The Army had its own forms and processes of authority and so in spite of the government 'pledge' that vaccination would not be compulsory for territorials and that inoculation remained voluntary for all, a circular was sent from Army Headquarters to commanding officers: "Every possible effort should be made, consistent with the military exigencies of the moment, to persuade men to undergo the process. Conscientious objectors should be informed that unless they submit to vaccination they are not likely to be of service in the field." 62

The NAVL insisted that the military were breaching the spirit of parliamentary law. Being denied foreign service in the early days of the war was a significant threat to young men keen to get to the Front. Other ways in which the military were seen to coerce men was in the denial of leave, assigning fatigue duties, bullying and in some cases discharge (resulting in shame for the men returning home). ${ }^{63}$

As with cases of negative side effects and deaths following inoculation, Chancellor and his colleagues bombarded the government with questions in parliament over specific cases in which the military machine appeared to have transgressed parliamentary law. Initially Tennant submitted to investigating each case and returned with explanations such as leave being denied because the un-inoculated may catch typhoid while on leave and threaten the health of the unit on their return; that inoculated men were chosen over the un-inoculated for 
service on the Front; ${ }^{64}$ that men who have served on the Front are entitled to more leave than others; ${ }^{65}$ that fatigue duties naturally fall to men who are not on bed rest after inoculation. ${ }^{66}$ As the questions multiplied, government initiated fewer investigations and provided more generic defences of military procedures: "Well, of course, military necessity has never known any law. I am not aware of any case where it has been said that military exigencies or necessities must be guided by conscientious objections." ${ }^{67}$ Similarly, "I am not prepared to intervene in any action which the General Officer Commanding-in-Chief, British Armies in France, may deem fit to take for the preservation of the health of the troops under his command. ${ }^{968}$

The notion of the corporate army appeared readily defensible for the purposes of medical consent no matter how well the NAVL and other proponents of Liberty pushed 'informed consent' in medicine. Yet compulsion in medicine was also beginning to feature in debates within medicine. At a Medico-Legal Society debate in March 1915, Sir William Collins, a medical doctor, gave a speech in favour of medical freedom and was recorded as stating that "Compulsion implied certitude, if not infallibility, and the assumption of pontifical airs had led some scoffers to say that priestcraft had forsaken the Church and taken up its abode with scientists and doctors." $" 69$

The notion of ethics in the doctor patient relationship can be seen as a feature of the 'personal hygiene' regime, since patient subjectivity is a prerequisite for any negotiation around treatment; ${ }^{70}$ yet it seemed that while civilian patients were developing their subjectivity; soldiers' bodies remained surrounded by dirt, not yet emancipated from nature and not yet thoughtful enough to have their subjectivity invoked. Conceivably, while the NAVL was 
thwarted by the press blackout and a widespread acceptance that individual freedom had to be sacrificed 'for the greater good' in war, their keeping alive the possibility of a conscience for all may at least have fed into the evolution of peacetime medical ethics.

\section{Peace Treaty}

Another subjugated knowledge that came under much fire in the early stages of the War was pacifism. ${ }^{71}$ Significant elements within the pacifist movement were Christian in origin (represented mainly by Quakers). Other forms, such as the Union for Democratic Control (UDC) headed by Norman Angell MP (Labour), were driven more by political and pragmatic objections (such as the dysgenic effects of war) and were associated with socialist leanings.

Since the government ultimately refrained from legislating on compulsory typhoid inoculation, the association between personal liberty and inoculation was never consolidated. But with the announcement of the 1916 Military Service Act, making military service compulsory for all men of a certain age, pacifism became another key debating ground for Liberty, finding plenty of discursive space in parliament and the media. Conscientious objection was thus cut away from its association with anti-vaccination and transplanted into pacifism. Following heated debates in parliament, a clause for conscientious objectors was included in the Military Service Act, adopting the terminology for which the Vaccination Acts provided a precedent.

Debates in parliament to establish the form and operation of the conscientious objector clause had serious implications for the task of generating a conscience for working class men currently filling the military ranks in France. Philip Snowden (Labour, UDC and also a 
teetotaller opposed to conscription) had made a strong case for adopting a method in line with the Vaccination Acts: "if an applicant makes a declaration that he has a conscientious objection, then the justice shall be compelled to accept that." ${ }^{, 72}$ But opponents succeeded in establishing more specific methods of interrogation (tribunals) to find evidence of a conscience. Debates on the equivalence of objections to vaccination versus military service brought up demeaning depictions of the working class conscience:

I myself remember the case of a man coming in and making a declaration for an exemption certificate, and afterwards I asked him why he objected to vaccination... and the reply was, 'I don't know much about it, but my wife does not like the child to keep her awake at night'... The reasons given by persons who apply for vaccination exemption certificates are usually so frivolous and so absurd that I think it was an unfortunate thing... to cite that case in support of this proposal. ${ }^{73}$

As noted earlier, conscience had previously become gendered and classed by association with the nineteenth century anti-vaccination movement. This statement represents a move to demasculinise men who would allow themselves to be dictated to by their wife. The working class male conscience was derogated and the mainstream press instead supported the transfer of a conscience to more educated, sincere men. The Times insisted that a conscientious objector must be willing to accept noncombat duties; pacifists who refused to co-operate on any level would be called 'shirkers' or 'slackers'. ${ }^{74}$ Lord Landsdowne (Conservative) was quoted on this distinction: "conscientious objectors started at one end with a deliberate shirker with whom nobody had compassion and at the other end was the deeply convinced sincere person who was entitled to whatever respect was due a thoughtful, educated and 
conscientious mind." 75 Evidently, a true conscientious objector would be a sincere educated man, unlike the 'frivolous' working class vaccination objector.

Similarly, the Daily Express quoted a Quaker speaking in the House of Commons: "The House next listened to a soulful speech by a ...Quaker...as the solemn voice continued, broken now and then by a quiver of deep feeling, the packed House sank to a dramatic silence."76 The respect accorded to the sincerity of the conscientious objector position was evident but those who refused non-combatant service were mocked and accorded the status of 'cranks', alongside the anti-vaccinationists. ${ }^{77}$

In spite of a degree of respect, both The Times and the Daily Express called for the disenfranchisement of all conscientious objectors. ${ }^{78}$ This stance was based on an argument that in a liberal society it was acceptable for one's conscience to dictate against killing, but if this meant that one would not fight to defend those liberties at home when under attack, then one should not benefit from a stake in the nation's democracy. Although remaining in favour of disenfranchisement, The Times appeared to become more sympathetic towards conscientious objectors over the course of the war. By late 1916, space was permitted for letters denouncing ill treatment of conscientious objectors: "Everyone is I believe, agreed that this bullying, if it exists, is a great and scandalous evil, and ought to be restrained."79

In 1917, Margaret Hobhouse published I appeal unto Caesar which specifically called for the acceptance of conscientious objectors who refused non-combatant service ('the absolutists'). Absolutists were not granted legal exemption and were imprisoned. The Times found space for a letter in praise of Hobhouse's book ${ }^{80}$ and also permitted space for two letters from 
Hobhouse herself at the end of the war, calling for the release of remaining prisoners: "I assure you that the feeling of the country ... has vitally changed since the armistice and that the Government and our Army will suffer seriously by the continued persecution of these men... the contempt in which they have been held is rapidly changing into sympathy." ${ }^{81}$

Also published in The Times was a letter to the Prime Minister calling for the same, "signed by over 160 literary and university men, Labour leaders, Bishops and clergy and other representative men and women," 82 the description of signatories emphasising an association of conscientious objector concerns with elite high-mindedness and intellectual leaning.

\section{Reparations}

Doctors had earned a special status during World War One. Given that doctors were in high demand for their medical services both at Home and abroad, although doctors were subject to conscription, a conscripted doctor was highly unlikely to fight on the Front. ${ }^{83}$ Instead, doctors sat on medical boards and on tribunals assessing men's fitness, considering claims for conscientious objector status, preparing, testing and administering vaccinations and inoculations, tending to the wounded, testing their blood and counting the dead. Doctors became arbiters of conscience, having a deciding impact on which men would serve, where they would serve and who would be imprisoned or court-martialled. The medical profession therefore became allied to the State during the war even though "Our duty is to save", a line from a contemporary poem quoted by Sir William Osler reflecting some misgivings within the profession about this relationship. ${ }^{84}$ 
In 1919 the Ministry of Health was established, finalising the move to establish Medicine as allied to the state. The Ministry of Health Act had been preceded in the early twentieth century by the Parliamentary Report as to the Practice of Medicine and Surgery by Unqualified Persons in the United Kingdom (1910) and the 1911 National Insurance Act. There was now a much clearer demarcation between orthodox medicine and 'alternative' medicine. The 1919 Ministry of Health Act also attempted to bring under its purview the policing of patent medicines by including a general power to secure "the avoidance of fraud in connection with alleged remedies therefor".

In contrast, the NAVL had been seen to have opposed the government during the war and to have threatened destabilisation of the Armed Forces by encouraging working class soldiers to stand up to military authority. This may have contributed to the increasing schism in medical practices which meant that 'cranks' and 'faddists' would remain permanently outside of orthodoxy with little room for legitimate critique, ambiguity or nuance around areas of uncertainty in medical science. By the end of the war, the decry of 'crank' and 'faddist' appeared to be more virile than 'unpatriotic', as the nation's taste for war had fizzled out and Medicine was the nation's saviour. 'Faddist' was as good as a diagnosis of unscientific. Indeed it appeared as a category among psychiatric diagnoses:

The faddist is a person who fixes upon some minor phase of conduct and exalts the cult of this mode into a religion...The negative faddist is anti-alcoholic, anti-carnivorous, antivaccinationist, anti-vivisectionist, anti-patriotist, anti-bellumist...The convictions of the faddist are the merest prejudices...he is constitutionally incapable of weighing evidence, of suspending his judgement or of entertaining doubts...To any infraction of the fad his 
conscience is morbidly sensitive: it quivers with hyperaesthesia; but in the treatment of the adversaries of his fad it is shocklingly callous. ${ }^{85}$

The faddist himself had become the patient, in need of a psychiatric medical gaze and incapable of rational thought. Legitimate scientific critique was derogated, since scientific method and knowledge was now held to be the purview of the illustrious scientist. Following the 1919 Ministry of Health Act, state medicine would control the health market from hereon. ${ }^{86}$

\section{Conclusion}

The nineteenth century anti-vaccination movement worked hard to expose a paradox within sanitary science which saw dirt (vaccine matter) being inserted into bodies rather than being kept out as sanitary science dictated. It gained public traction and may have contributed to both improvements in vaccination procedures as well as establishing the principle of freedom to choose, a principle widely valued by the British. In the early twentieth century, war, mass recruitment of soldiers and a new threat to personal liberty in the form of typhoid inoculation provided the NAVL with a new campaign focus. Cotemporary with the shift from sanitary science to personal hygiene as public health discourses, the NAVL expanded the rhetoric of 'conscience', emphasising medical freedom alongside scientific arguments about effectiveness of vaccines and critique of laboratory based diagnosis.

Although the NAVL had some impact on public debate through leafleting of soldiers, distribution of literature and with at least one advocate in parliament, its overall aims were opposed by the much more influential newspapers which rejected the idea of ordinary 
soldiers having a conscience, although supported forms of personal liberty for educated, sincere and philosophical men. This tied in with the development of conscientious objection to war and pacifism which was seen as a more philosophical educated position than a 'frivolous' disliking of vaccination among working class men in thrall to their wives. Soldiers (largely made up of working class men) had, by Act of Parliament and media complicity, failed to be emancipated from nature. By the end of the War, millions of working class bodies were strewn across European battlefields and gruesome images of trench warfare which had been suppressed during the war began to emerge. The image of the soldier's body had begun as one of "sinew and muscle" with "strength and endurance" 87 but would end the war with all of its bone, muscle, sinew and blood grotesquely exposed, surrounded by dirt and unsuited to house a genteel conscience.

It is possible that public awareness of the deterioration of some soldier's minds in the form of the newly classified 'shell-shock' may also have fed into a public image of soldiers bodies as being unfit for a conscience, although NAVL literature does not engage significantly with this topic. Ultimately, the NAVL choice of 'conscience' as a propaganda device was unsuccessful in preventing compulsion in all but name. Yet, predating more well-known controversies emerging later on in the century such as eugenics, the Holocaust and the Nuremburg trials, the discursive contributions of the NAVL concerning conscience during this episode are likely to have contributed to an emergent narrative around medical freedom and informed consent that would continue to be a feature of vaccination debates throughout the twentieth century and beyond. 
Although typhoid inoculation was never made compulsory by law, it was enforced through coercive military practices. The anti-vaccination movement was depicted as unpatriotic and labelled as a crank organisation, its arguments, beliefs and practices deemed vexatious and dangerous. This denigration of alternative views and critique of mainstream medicine occurred within a context of both national crisis as well as one in which the medical profession was seeking to establish itself more firmly, to demarcate boundaries of knowledge and claim authority over the field of medical practice. The medical profession succeeded in allying itself to the state during the War, quashing critics and alternative practices, laying the foundation for modern British state Medicine.

This power dynamic has continued throughout the twentieth century and persists today with 'anti-vax' having become a derogatory term for any critique of the practice or science underpinning vaccination. During the COVID-19 pandemic, which perhaps has in common a national crisis along with uncertainty around scientific and medical understanding, it is possible to observe parallels in terms of the degree of scorn directed at challenges to scientific and medical expertise, vilifying critical perspectives as belonging to irrational, dangerous, selfish or unintelligent people. It is possible to observe parallels in the way that mainstream media operate to influence public attitudes and determine which scientists and medical experts should be endorsed versus condemned.

Given that scientific and medical theories are in constant development and that ideas that once seemed cutting edge are now seen as archaic or barbaric, it seems useful to consider the role and impact of dissenting ideas historically and in the present. Arguably, the organised expression of subjugated medical knowledge allows the public to hear a range of ideas and 
forces established experts to refine their scientific arguments to counter what they believe to be misunderstandings or misinformation. At various points in history, critics of the medical establishment may have influenced governments to hold back from draconian medical laws which might have been counter-productive to public trust in medicine and uptake of public health measures. Some authors argue, therefore, that medical experts should do more to engage with the public rather than silence critics and turn to coercion and compulsion. Supporting this position, an ethnographic study of contemporary narratives and practices of people adhering to 'fringe' medicine including anti-vaccination found that adherents do not exclusively contest or comply with mainstream scientific medicine, but can do both and that many uphold "scientific ideals of ethical conduct, rational scepticism and evidence-based knowledge, albeit in ways that may clash with medical knowledge." 88 The authors found that when exposed to critique, people embracing critical views felt able to differentiate between 'extremists' and 'rational critics' and concluded that their findings point to the "need for the medical establishment to develop public engagement with its critical or 'othered' groups".

In the aftermath of war which saw the birth of the Ministry of Health, the NAVL contributed to an evolving medical discourse around compulsion and medical freedom. During the twentieth century, the ethical-political relationship between doctor and patient became as important as the clinical skills and knowledge of the practitioner. The NAVL continued to agitate vehemently against the medical 'tyranny' of the Ministry of Health and in 1921 after vigorous debate amongst its members, expanded its objects to include "vindication of the legitimate freedom of the subject in matters of medical treatment"; ${ }^{89}$ in line with their US and Canadian counterparts who labelled themselves 'Medical Freedom Leagues'. The NAVL campaigns after World War One included abolishing enforced adenoid removal in children 
attending school, which the medical establishment today would probably agree was unnecessary and potentially harmful. Given that 2021 will continue to feature large scale roll-out of vaccination programmes for COVID-19, there are likely to be lively debates around choice and compulsion as well as safety and consent. Although forms and influence of different types of media have moved on and diversified significantly since the early twentieth century, the history of the role and impact of the British anti-vaccination movement on medical practice and knowledge as well as the responses of the press, the public, politicians and the medical establishment may be a useful context against which to consider the debates and positions that will emerge.

\section{Notes}

\footnotetext{
${ }^{1}$ Durbach, Bodily Matters - The Anti-Vaccination Movement in England 1983-1907. (See Chapter 5)

${ }^{2}$ Durbach. (See Chapter 6)

${ }^{3}$ Durbach. (See Chapter 7)

${ }^{4}$ Durbach. (See Chapter 2)

${ }^{5}$ Durbach. (See Chapter 6)

${ }^{6}$ Mill, On Liberty. p27

7 Lewis, "The Prevention of Diphtheria in Canada and Britain 1914-1945."

${ }^{8}$ Saks, "The Wheel Turns? Professionalisation and Alternative Medicine in Britain."

${ }^{9}$ Dixon, The Divine Feminine: Theosophy and Feminism in England. p150-1

1. ${ }^{10}$ Johnson, Larkin, and Saks, "State Control and the Health Professions in the United Kingdom."

${ }^{11}$ Armstrong, "Public Health Spaces and the Fabrication of Identity."

12 Durbach, Bodily Matters - The Anti-Vaccination Movement in England 1983-1907. (See Chapter 6)

${ }^{13}$ Smith, "Louis Pasteur, the Father of Immunology?"

${ }^{14}$ Armstrong, "Public Health Spaces and the Fabrication of Identity."

${ }^{15}$ Durbach, "Class, Gender, and the Conscientious Objector to Vaccination, 1898-1907." p59

${ }^{16}$ Durbach. p82

${ }^{17}$ Walker, "The Greater Good: Agency and Inoculation in the British Army, 1914-18." (See p141-142)

${ }^{18}$ Hardy, "'Straight Back to Barbarism': Antityphoid Inoculation and the Great War, 1914."

${ }^{19}$ Linton, "Was Typhoid Inoculation Safe and Effective during World War I? Debates within German Military Medicine."

${ }^{20}$ Walker, "The Greater Good: Agency and Inoculation in the British Army, 1914-18." (See p152)

${ }^{21}$ Durbach, Bodily Matters - The Anti-Vaccination Movement in England 1983-1907. (See Chapter 2)

22 Dodds, Is Liberalism Dead? A Restatement and an Appeal. p39

${ }^{23}$ National Anti-Vaccination League, "The Sinew and the Muscle of the Forces."

${ }^{24}$ National Anti-Vaccination League, "The Downfall of Prussianism."

${ }^{25}$ National Anti-Vaccination League, "Vaccination and the Territorials."

${ }^{26}$ National Anti-Vaccination League, "The Word of Promise to Our Ear."

${ }^{27}$ Hardy, “'Straight Back to Barbarism': Antityphoid Inoculation and the Great War, 1914." p270

${ }^{28}$ Hardy. p275
} 
${ }^{29}$ Wright, "Inoculation of Troops: The Case for Compulsion."

${ }^{30}$ National Anti-Vaccination League, "Dishonest Methods."

${ }^{31}$ National Anti-Vaccination League, "Mr Thirtle's Notes."

32 National Anti-Vaccination League, "Our Disloyalty."

${ }^{33}$ National Anti-Vaccination League, "The Dismal Dean."

${ }^{34}$ National Anti-Vaccination League, "Soldiers' Protests."

${ }^{35}$ HC Deb, "Vote A - Number of Land Forces"

${ }^{36} \mathrm{HC}$ Deb.

${ }^{37}$ Linton, "Was Typhoid Inoculation Safe and Effective during World War I? Debates within German Military Medicine." p102

${ }^{38}$ Carroll, "Medical Police and the History of Public Health"; Bryder, Below the Magic Mountain: A Social History of Tuberculosis in Twentieth-Century Britain; Lewis, "The Prevention of Diphtheria in Canada and Britain 1914-1945"; Hennock, "Vaccination Policy Against Smallpox, 1835-1914: A Comparison of England with Prussia and Imperial Germany."

${ }^{39}$ Walker, "The Greater Good: Agency and Inoculation in the British Army, 1914-18."

${ }^{40}$ Carroll, "Medical Police and the History of Public Health"; Bryder, Below the Magic Mountain: A Social History of Tuberculosis in Twentieth-Century Britain; Lewis, "The Prevention of Diphtheria in Canada and Britain 1914-1945."

${ }^{41}$ HC Deb, “(9 February 1915), Vote A - Number of Land Forces, Vol. 69, Col. 408-540. Available at: Https://Hansard.Parliament.Uk/."

42 National Anti-Vaccination League, "Ultimate Effects Steadily Ignored."

${ }^{43}$ National Anti-Vaccination League, "THe Health of Our Field Army."

${ }^{44}$ National Anti-Vaccination League, "Clinical and Bacteriological Diagnosis."

${ }^{45}$ National Anti-Vaccination League, "The Suggestion of Falsehood."

${ }^{46}$ Osler, "Antityphoid Vaccination, British Medical Journal."

${ }^{47}$ Heggie, “Lies, Damn Lies, and Manchester's Recruiting Statistics: Degeneration as an 'Urban Legend' in Victorian and Edwardian Britain."

${ }^{48}$ Hardy, "'Straight Back to Barbarism': Antityphoid Inoculation and the Great War, 1914." p273

${ }^{49}$ McEwen, "The National Press during the First World War: Ownership and Circulation."

${ }^{50}$ Bingham, "Ignoring the First Draft of History?" (See p311)

${ }^{51}$ Wright, "Inoculation of Troops: The Case for Compulsion."

52 National Anti-Vaccination League, "Mr Bernard Shaw Silenced."

53 Medical Correspondent, "Health of the Troops."

54 "War and Disease."

55 Turner, "Anti-Typhoid Inoculation."

56 "Matters of Moment."

${ }^{57}$ G.C.P., "The Benificent Bugs."

58 HC Deb, "Anti-Typhoid Inoculation"

59 HC Deb, "Vote A - Number of Land Forces"

60 National Anti-Vaccination League, "The Supress Gang."

${ }^{61}$ Company Officer, "Anti-Enteric Inoculation."

62 National Anti-Vaccination League, "Inoculations in the Army"; HC Deb, "Vaccination Regulations"

${ }^{63}$ Walker, "The Greater Good: Agency and Inoculation in the British Army, 1914-18."

${ }^{64}$ HC Deb, “(23 November 1914) Inoculation, Vol. 68 Col. 786. Available at: Https://Hansard.Parliament.Uk/."

65 HC Deb, "Inoculation against Disease"

${ }^{66} \mathrm{HC}$ Deb, "Number of Land Forces"

${ }^{67} \mathrm{HC}$ Deb.

68 HC Deb, "Vaccination and Inoculation"

${ }^{69}$ National Anti-Vaccination League, "Sir William Collins on Compulsory Medical Treatment."

${ }^{70}$ Armstrong, A New History of Identity: A Sociology of Medical Knowledge. (See in particular chapters 7, 8 and 9)

${ }^{71}$ Goulton, The Main Illusions of Pacifism: A Criticism of Mr. Norman Angell and the Union of Democratic Control. This is a 300 page book published in 1916 containing several appendices attacking in considerable detail the concepts, practices and individual proponents of pacifism

72 National Anti-Vaccination League, "Our Question in Parliament."

This is the accepted version. Published version citation:

McPherson S. War of conscience: antivaccination and the battle for medical freedom during World War I

Medical Humanities Published Online First: 24 May 2021. doi: 10.1136/medhum-2020-012069 


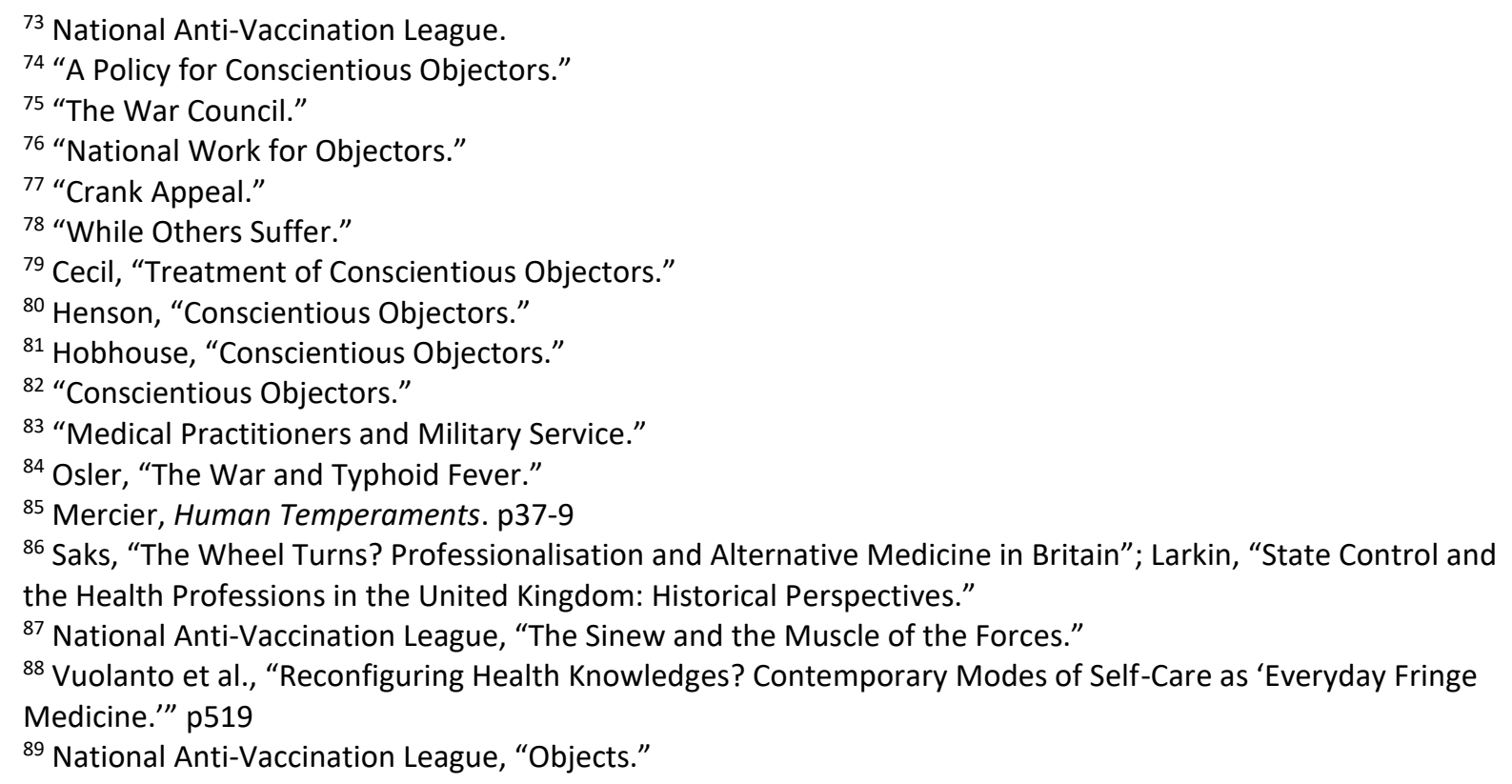




\section{Bibliography}

“A Policy for Conscientious Objectors.” The Times, July 6, 1916.

Armstrong, David. A New History of Identity: A Sociology of Medical Knowledge. Palgrave Macmillan, 2002.

—. "Public Health Spaces and the Fabrication of Identity." Sociology 27, no. 3 (August 2, 1993): 393-410. https://doi.org/10.1177/0038038593027003004.

Bingham, Adrian. "Ignoring the First Draft of History?” Media History 18, no. 3-4 (August 2012): 311-26. https://doi.org/10.1080/13688804.2012.721644.

Bryder, Linda. Below the Magic Mountain: A Social History of Tuberculosis in TwentiethCentury Britain. Oxford: Oxford University Press, 1988.

Carroll, Patrick E. "Medical Police and the History of Public Health.” Medical History 46, no. 4 (October 16, 2002): 461-94. https://doi.org/10.1017/S0025727300069702.

Cecil, H. “Treatment of Conscientious Objectors.” The Times, October 17, 1916.

Company Officer. “Anti-Enteric Inoculation.” The Times, February 12, 1915.

“Conscientious Objectors,” January 4, 1919.

“Crank Appeal.” Daily Express, June 13, 1916.

Dixon, Joy. The Divine Feminine: Theosophy and Feminism in England. Baltimore, Maryland: John Hopkins University Press, 2001.

Dodds, E. Is Liberalism Dead? A Restatement and an Appeal. London: George Allen \& Unwin Ltd., 1920. https://archive.org/details/isliberalismdead00doddrich.

Durbach, Nadia. Bodily Matters - The Anti-Vaccination Movement in England 1983-1907.

North Carolina: Duke University Press, 2005.

Durbach, Nadja. "Class, Gender, and the Conscientious Objector to Vaccination, 1898- 
1907." Journal of British Studies 41, no. 1 (January 10, 2002): 58-83.

https://doi.org/10.1086/386254.

G.C.P. “The Benificent Bugs.” Daily Express, January 30, 1915.

Goulton, GG. The Main Illusions of Pacifism: A Criticism of Mr. Norman Angell and the Union of Democratic Control. Cambridge: Bowes \& Bowes, 1916.

Hardy, Anne. “'Straight Back to Barbarism': Antityphoid Inoculation and the Great War, 1914." Bulletin of the History of Medicine 74, no. 2 (December 17, 2000): 265-90. http://www.jstor.org/stable/44445447.

HC Deb. “(10 February 1915), Number of Land Forces, Vol. 69, Col. 600-677. Available at: Https://Hansard.Parliament.Uk/," n.d. . “(10 March 1915), Inoculation against Disease, Vol. 70 Col. 1427W. Available at: Https://Hansard.Parliament.Uk/," n.d.

“(19 October 1916), Vaccination and Inoculation, Vol. 86 Col. 745W. Available at: Https://Hansard.Parliament.Uk/," n.d. “(23 November 1914) Inoculation, Vol. 68 Col. 786. Available at:

Https://Hansard.Parliament.Uk/," n.d. ."(26 August 1914). Vaccination Regulations, Vol. 66 Col. 35. Available at: Https://Hansard.Parliament.Uk/," n.d. . “(5 May 1915) Anti-Typhoid Inoculation, Vol. 71, Col.1097,” n.d. . “(9 February 1915), Vote A - Number of Land Forces, Vol. 69, Col. 408-540. Available at: Https://Hansard.Parliament.Uk/," n.d.

Heggie, V. “Lies, Damn Lies, and Manchester’s Recruiting Statistics: Degeneration as an 'Urban Legend' in Victorian and Edwardian Britain.” Journal of the History of Medicine and Allied Sciences 63, no. 2 (August 30, 2007): 178-216. 
https://doi.org/10.1093/jhmas/jrm032.

Hennock, E. P. "Vaccination Policy Against Smallpox, 1835-1914: A Comparison of

England with Prussia and Imperial Germany." Social History of Medicine 11, no. 1

(April 1, 1998): 49-71. https://doi.org/10.1093/shm/11.1.49.

Henson, H. “Conscientious Objectors.” The Times, September 15, 1917.

Hobhouse, Margaret. “Conscientious Objectors.” The Times, April 4, 1919.

Johnson, Terry, Gerry Larkin, and Mike Saks. "State Control and the Health Professions in the United Kingdom." In Health Professionals and the State in Europe, edited by Terry Johnson, Gerry Larkin, and Mike Saks. Routledge, 2005.

https://doi.org/10.4324/9780203991602.

Larkin, G. "State Control and the Health Professions in the United Kingdom: Historical Perspectives." In Health Professionals and the State in Europe, edited by T Johnson, G Larkin, and M Saks, 45-54. Routledge, 1995.

Lewis, Jane. "The Prevention of Diphtheria in Canada and Britain 1914-1945." Journal of Social History 20, no. 1 (December 17, 1986): 163-76.

http://www.jstor.org/stable/3788281.

Linton, D S. "Was Typhoid Inoculation Safe and Effective during World War I? Debates within German Military Medicine.” Journal of the History of Medicine and Allied Sciences 55, no. 2 (April 2000): 101-133. https://doi.org/10.1093/jhmas/55.2.101.

“Matters of Moment.” Daily Express, February 10, 1915.

McEwen, J.M. "The National Press during the First World War: Ownership and Circulation." Journal of Contemporary History 17, no. 3 (1982): 459-86.

https://doi.org/https://www.jstor.org/stable/260556.

Medical Correspondent. "Health of the Troops.” The Times, February 11, 1916. 
"Medical Practitioners and Military Service.” British Medical Journal 1, no. 623 (1918): $623-24$.

Mercier, Charles. Human Temperaments. London: The Scientific Press Ltd, 1916.

Mill, J.S. On Liberty. London: John W. Parker \& Son, 1859.

National Anti-Vaccination League. "Clinical and Bacteriological Diagnosis." Vaccination Inquirer and Health Review 38, no. 447 (1916): 138.

_. "Dishonest Methods." Vaccination Inquirer and Health Review 36, no. 427 (1914):

227.

—_. "Inoculations in the Army." Vaccination Inquirer and Health Review 36, no. 427 (1914): 228.

. "Mr Bernard Shaw Silenced.” Vaccination Inquirer and Health Review 37, no. 431

(1915): 45.

. “Mr Thirtle's Notes.” Vaccination Inquirer and Health Review 36, no. 428 (1914):

267.

__. "Objects." Vaccination Inquirer and Health Review 43, no. 505 (1921): 49.

—. "Our Disloyalty.” Vaccination Inquirer and Health Review 36, no. 428 (1914): 250.

__. "Our Question in Parliament." Vaccination Inquirer and Health Review 38, no. 443

(1916): 36 .

—. "Sir William Collins on Compulsory Medical Treatment." Vaccination Inquirer and Health Review 37, no. 434 (1915): 130.

—_. "Soldiers' Protests." Vaccination Inquirer and Health Review 37, no. 431 (1915):

49.

. “The Dismal Dean.” Vaccination Inquirer and Health Review 37, no. 430 (1915):

21. 
—_. "The Downfall of Prussianism." Vaccination Inquirer and Health Review 37, no.

430 (1915): 2.

. "THe Health of Our Field Army.” Vaccination Inquirer and Health Review 36, no.

429 (2014): 273.

—. "The Sinew and the Muscle of the Forces." Vaccination Inquirer and Health Review 36, no. 426 (1914): 210.

. "The Suggestion of Falsehood." Vaccination Inquirer and Health Review 37, no. 431

(1915): 48.

—. "The Supress Gang." Vaccination Inquirer and Health Review 37, no. 431 (1915):

51.

. "The Word of Promise to Our Ear." Vaccination Inquirer and Health Review 36, no. 426 (1915): 244.

—. "Ultimate Effects Steadily Ignored." Vaccination Inquirer and Health Review 36, no. 427 (1914): 226.

—. "Vaccination and the Territorials." Vaccination Inquirer and Health Review 36, no. 426 (1914): 220.

"National Work for Objectors.” Daily Express, January 20, 1916.

Osler, William. “Antityphoid Vaccination, British Medical Journal.” British Medical Journal 2, no. 2806 (1914): 647.

—. "The War and Typhoid Fever.” British Medical Journal 2, no. 909 (1914): 909-13.

Saks, M. "The Wheel Turns? Professionalisation and Alternative Medicine in Britain." Journal of Interprofessional Care 13, no. 2 (1999): 129-38.

Smith, Kendall A. “Louis Pasteur, the Father of Immunology?” Frontiers in Immunology 3 (2012). https://doi.org/10.3389/fimmu.2012.00068. 
“The War Council.” The Times, November 15, 1917.

Turner, A. “Anti-Typhoid Inoculation.” The Times, February 15, 1915.

Vuolanto, Pia, Harley Bergroth, Johanna Nurmi, and Suvi Salmenniemi. "Reconfiguring Health Knowledges? Contemporary Modes of Self-Care as ‘Everyday Fringe Medicine."” Public Understanding of Science 29, no. 5 (July 27, 2020): 508-23. https://doi.org/10.1177/0963662520934752.

Walker, Simon H. "The Greater Good: Agency and Inoculation in the British Army, 191418.” Canadian Bulletin of Medical History 36, no. 1 (April 2019): 131-57. https://doi.org/10.3138/cbmh.280-082018.

“War and Disease." The Times, October 1, 1914.

"While Others Suffer.” Daily Express, November 16, 1917.

Wright, Almroth. "Inoculation of Troops: The Case for Compulsion." The Times, September $28,1914$. 